\title{
Penerapan Pendekatan Sains Teknologi Lingkungan Masyarakat untuk Meningkatkan Aktivitas dan Hasil Belajar Biologi di SMAN 1 Kota Padang
}

\author{
Reny Dwi Riastuti \\ Progam Studi Pendidikan Biologi, STKIP PGRI Lubuklinggau \\ JL. Mayor Toha Tabapinggin Lubuklinggau \\ surat elektronik: renydwiriastuti@,ymail.com
}

\begin{abstract}
ABSTRAK
Artikel ini memaparkan hasil penelitian tentang Penerapan Pendekatan Sains Teknologi Lingkungan Masyarakat untuk Meningkatkan Aktivitas dan Hasil Belajar Bioteklogi di SMAN I Kotapadang. Penelitian ini bertujuan untuk meningkatkan Aktivitas dan Hasil Belajar Biologi di SMAN I Kotapadang melalui penerapan pendekatan Sains Teknologi Lingkungan Masyarakat. Jenis penelitian ini adalah Penelitian Tindakan Kelas (PTK) dengan dua siklus. Langkah-langkah dalam penelitian ini meliputi: perencanaan (planning) merupakan langkah pertama dalam setiap kegiatan, 2) tindakan (action) merupakan realisasi dari rencana yang dibuat, 3) observasi (observation) bertujuan untuk mengetahui kualitas tindakan yang dilakukan, 4) refleksi (reflection) bertujuan untuk melihat atau merenungkan kembali apa yang telah dilakukan dan apa dampaknya bagi proses belajar siswa. Pengumpulan data berupa lembar observasi dan tes, yang diolah secara deskriptif. Analisis data observasi menggunakan skala penilaian pengukuran, dan untuk hasil tes dengan persen ketercapaian. Berdasarkan hasil penelitian diperoleh nilai rata-rata pada siklus I. aspek afektif adalah 69,I4 dengan ketuntasan klasikal 43,75\%; aspek psikomotorik adalah 75,2I dengan ketuntasan klasikal 68,75\%, dan aspek kognitif adalah 6,2 dengan ketuntasan 43\%. Sedangkan pada siklus ke II pada aspek afektif adalah 76,36 dengan ketuntasan klasikal 90,62\%; aspek psikomotorik adalah 83,78 dengan ketuntasan klasikal 100\%; dan aspek kognitif adalah 7,3 dengan ketuntasan 74\%.
\end{abstract}

Kata kunci: Pendekatan Sains Teknologi Lingkungan Masyarakat, Aktivitas, Hasil Belajar.

\section{Pendahuluan}

Dalam dasa warsa terakhir ini ilmu pengetahuan telah berkembang dengan pesat, dan membawa dampak terhadap hampir setiap aspek dalam hidup dan dan kehidupan manusia. Diantaranya berbagai bidang yang berpengaruh oleh masalah tersebut, bidang pendidikan berada pada posisi yang paling depan. Dunia pendidikan berhadapan langsung dengan kemajuan tersebut, dan dituntut untuk mampu menyesuaikan diri dan dapat mengantisifasinya. Atas dasar inilah berbagai faktor yang berperan dalam pendidikan secara umum, khususnya dalam pendidikan sains harus senantiasa tanggap dan membenahi diri agar dapat mengikuti perkembangan tersebut. Dengan kata lain dalam mengantisipasi kemajuan sains dan teknologi perlu dilakukan berbagai pembaharuan dan perbaikan dalam dunia pendidikan pada umumnya dan pendidikan sains pada khususnya, (Winarni, 2009:69).

Pendidikan adalah usaha sadar untuk menyiapkan peserta didik melalui kegiatan bimbingan, pengajaran, dan latihan bagi peranannya di masa yang akan datang.
(UU RI No.2 Tahun I989, Bab I, Pasal I), Pendidikan adalah suatu proses dalam rangka mempengaruhi peserta didik supaya mampu menyesuaikan diri sebaik mungkin dengan lingkungannya, dan dengan demikian akan menimbulkan perubahan pada dirinya (Hamalik, 200I:44).

Sains merupakan pengetahuan manusia tentang alam yang diperoleh dengan cara terkontrol dan sistematik serta dapat diuji dan dibuktikan kebenarannya. Oleh karena itu, dalam pembelajaran sains seyogyanya diciptakan kondisi agar siswa selalu aktif untuk ingin tahu terhadap permasalahan alam sekitar. Sehingga siswa dapat menggali potensi-potensi yang ada dalam dirinya untuk dikembangkan dan nantinya dengan potensi yang dimiliki siswa mampu mengatasi setiap tantangan dan rintangan dalam kehidupan yang cepat berubah apalagi dengan perkembangan teknologi yang semakin pesat.

Untuk mempelajari suatu materi sains yang baru, pengalaman belajar yang lalu dari seseorang itu akan mempengaruhi terjadinya proses belajar sains tersebut. Apalagi diajarkan menurut cara yang tepat lalu dari 
seseorang itu akan mempengaruhi terjadinya proses belajar misalnya diajarkan dengan menggunakan pendekatan Sains Lingkungan Teknologi Masyarakat (Winarni, 2009:69). Pada pendekatan ini siswa dihadapkan pada suatu masalah yang terjadi di lingkungan sekitar kita sebagai akibat dari pengembangan atau penggunaan teknologi yang meresahkan kehidupan masyarakat. Dalam proses pembelajarannya siswa diajak untuk mencari solusi untuk mengatasi masalah tersebut dengan menggunakan dasar atau menerapkan prinsip-prinsip sains.

\section{Metode Penelitian}

Jenis penelitian ini adalah Penelitian Tindakan Kelas (PTK) dengan dua siklus.

Instrument penelitian: Instrumen penelitian adalah alat yang digunakan untuk mengamati variabel yang muncul dalam penelitian. Instrument penelitian yang digunakan adalah: a) Lembar observasi, Lembar observasi digunakan untuk mengamati aktifitas siswa dan guru selama proses pembelajaran berlangsung. Pengamatan dilakukan selama kegiatan belajar mengajar berlangsung, yaitu dari awal kegiatan sampai guru menutup pelajaran. b) Tes hasil belajar, Tes dilaksanakan berupa tes tertulis. Tes digunakan untuk memperoleh informasi tentang hasil belajar siswa pada pokok bahasan bioteknologi. Tes dilakukan dalam dua jenis yaitu tes awal dan tes akhir. Bentuk tes adalah pilihan ganda yang terdiri dari IO soal. Soal tes diadopsi dari buku dengan mengacu pada indikator dan tujuan pembelajaran. c) Afektif, Penilaian ini dilakukan terhadap siswa pada saat proses pembelajaran berlangsung untuk mengetahui keterlibatan siswa. d) Psikomotorik, Penilaian ini dilakukan terhadap siswa pada saat proses pembelajaran berlangsung untuk mengetahui keterlibatan siswa.

Prosedur penelitian: Prosedur penelitian tindakan kelas ini akan dilaksanakan persiklus, setiap siklusnya terdiri dari empat tahapan, yaitu perencanaan, tindakan, pengamatan dan refleksi. Tahap-tahap penelitian menurut Winarni (2009) yaitu: I) perencanaan (planning) merupakan langkah pertama dalam setiap kegiatan, 2) tindakan (action) merupakan realisasi dari rencana yang dibuat, 3) observasi (observation) bertujuan untuk mengetahui kualitas tindakan yang dilakukan, 4) refleksi (reflection) bertujuan untuk melihat atau merenungkan kembali apa yang telah dilakukan dan apa dampaknya bagi proses belajar siswa. Rincian dari siklus tersebut adalah sebagai berikut:

\section{Siklus I}

Perencanaan: a) Menyusun silabus, b) Menyusun rencana pelaksanaan pembelajaran (RPP), c) Mempersiapkan tes awal beserta kunci jawaban, d) Mempersiapkan lembar observasi aktivitas siswa dan guru beserta inidikatornya, e) Mempersiapkan lembar observasi afektif dan psikomotorik, f) Mempersiapkan lembar tes akhir siklus I berupa lembar tertulis dengan IO soal pilihan ganda serta membuat kunci jawaban

Tindakan atau pelaksanaan

Pada siklus I pembelajaran dilakukan sebanyak I kali pertemuan yaitu dengan alokasi waktu 2x45 menit. Materi yang dipelajari pada siklus I adalah dengan Standar Kompetensi 5.I Menjelaskan arti, prinsip dasar dan jenis-jenis bioteknologi Adapun tahap-tahap pembelajaran siklus I dengan menggunakan pendekatan Sains Lingkungan Teknologi Masyarakat adalah sebagai berikut:

Kegiatan awal

\section{Tahap invitasi}

I. Pra kegiatan

a. Siswa mengucapkan salam dan guru menjawab, kemudian dilanjutkan dengan doa bersama.

b. Guru mengecek kehadiran siswa

c. Guru mengkondisikan siswa untuk siap belajar

2. Kegiatan pembuka / pendahuluan (I0 menit)

a. Guru melakukan apersepsi tentang bioteknologi

b. Guru memberikan isu-isu tentang pandangan tempe kepada siswa.

I) Guru bertanya kepada siswa, apakah kalian pernah makan tempe? (siswa menjawab: pernah)

2) Guru menanyakan kembali kepada siswa, apa rasanya? (siswa menjawab: gurih, tidak enak,bosan)

3) Kemudian guru melanjutkan dengan menanyakan kepada siswa, Terbuat dari apa tempe itu? (Siswa menjawab: dari kedelai)

4) Guru menanyakan kepada siswa,bagaimana cara membuatnya? (siswa menjawab: tidak tahu, di injak, di kasih ragi, beranekaragam jawaban dari siswa)

c. Dari jawaban siswa, guru menjelaskan pengertian dari bioteknologi serta memberikan contoh produk bioteknologi.

d. Guru menyampaikan tujuan pembelajaran dan langkah kegiatan pembelajaran yang akan dilaksanakan.

Kegiatan inti 70 menit

\section{Tahap explorasi}

I. Guru mengkoordinir siswa dalam pembelajaran Saling temas

2. Guru menjelaskan menjelaskan arti, prinsip dasar dan jenis-jenis bioteknologi

3. Siswa menyimpulkan hasil dari pembelajaran Penutup I0 menit

Tahap action

I. Guru memberikan tes evaluasi pembelajaran.

2. Guru menugaskan kepada siswa untuk mencari tahu cara membuat tempe. 


\section{Observasi}

Pada siklus I dilaksanakan observasi terhadap kegiatan belajar mengajar yang sedang berlangsung dan menggunakan lembar observasi yang telah dibuat. Selama pelaksanaan kegiatan belajar mengajar dilakukan observasi oleh pengamat yaitu peneliti sendiri. Pada akhir pelaksanaan siklus I diadakan tes selama I5 menit untuk mengukur hasil belajar siswa.

\section{Refleksi}

Pada tahap ini digunakan analisis terhadap seluruh penilaian, baik yang menyangkut penilaian proses (observasi guru dan siswa, afektif dan psikomotorik). Dengan demikian maka dapat diketahui hal-hal apa saja yang telah tercapai dan hal apa saja yang masih perlu diperbaiki pada siklus berikutnya.

\section{Siklus II}

Perencanaan, pada siklus II merupakan tindak lanjut dari kegiatan pembelajaran pada siklus I, kegiatan yang dilakukan pada tahap perencanaan adalah: a) Menyusun silabus, b) Menyusun rencana pelaksanaan pembelajaran (RPP), c) Menyiapkan lebar kerja siswa (LKS) beserta kunci jawaban, d) Merancang pembelajaran dengan membentuk kelompok, e) Mempersiapkan lembar observasi aktivitas siswa dan guru beserta inidikatornya, f) Mempersiapkan lembar observasi afektif dan psikomotorik, g) Mempersiapkan lembar tes akhir siklus II berupa lembar tertulis dengan IO soal pilihan ganda serta membuat kunci jawaban.

Tindakan atau pelaksanaan

Pada siklus II pembelajaran dilakukan sebayak 2 kali pertemuan yaitu dengan alokasi waktu $4 \times 45$ menit. Materi yang dipelajari pada siklus II adalah dengan standar kompetensi 5.2 Menjelaskan dan menganalisis peran bioteknologi serta implikasi hasil-hasil bioteknologi pada Saling temas. Adapun tahap-tahap pembelajaran siklus II dengan menggunakan pendekatan Sains Lingkungan Teknologi Masyarakat adalah sebagai berikut:

\begin{tabular}{|l|}
\hline \multicolumn{2}{|c|}{ Tahap invitasi } \\
\hline I. Pra kegiatan \\
a. Siswa mengucapkan salam dan guru \\
menjawab, kemudian dilanjutkan dengan doa \\
bersama. \\
b. Guru mengecek kehadiran siswa \\
c. Guru mengkondisikan siswa untuk siap belajar \\
2. Kegiatan pembuka / pendahuluan (I0 menit) \\
a. Guru melakukan apersepsi tentang \\
bioteknologi \\
b. Guru memberikan isu-isu tentang pandangan \\
tempe kepada siswa. \\
c. Guru bertanya kepada siswa bagaimana cara \\
membuat tempe yang baik dan benar? (siswa \\
menjawab caranya melalui tahap mencuci, \\
merebus, merendam, merebus kembali, di beri \\
ragi dan dibungkus.
\end{tabular}

d. Dari jawaban siswa, guru menjelaskan cara membuat tempe yang tepat.

e. Guru menyampaikan tujuan pembelajaran dan langkah kegiatan pembelajaran yang akan dilaksanakan

Kegiatan inti 70 menit

\section{Tahap explorasi}

I. Guru mengkoordinir siswa dalam pembelajaran Saling temas

2. Guru menyuruh siswa duduk dalam kelompok yang sudah ditentukan, dalam kelompok terdiri atas 6 orang (yang mana siswa yang bersifat heterogen (jenis kelamin, ras,etnik, kemampuan akademik yang berbeda).

3. Guru menjelaskan langkah kerja yang harus dilakukan oleh setiap kelompok

4. Setelah itu setiap kelompok siswa melakukan diskusi dan dilanjutkan dengan eksperimen sesuai dengan petunjuk kerja.

5. Guru membimbing siswa untuk melakukan eksperimen.

6. Siswa menjawab pertanyaan dalam LKS

7. Siswa menyimpulkan hasil dari eksperimen

Penutup 10 menit

\begin{tabular}{ll}
\hline \multicolumn{2}{c}{ Tahap action } \\
\hline I. Guru menugaskan kepada setiap kelompok untuk \\
menyelesaikan tugas praktikum di rumah. \\
2. Guru membimbing siswa dalam membuat slogan- \\
slogan untuk masyarakat \\
3. Guru menutup pembelajaran \\
\hline
\end{tabular}

Observasi

Pada pelaksanaan siklus 2 ini dilaksanakan observasi terhadap kegiatan belajar mengajar yang sedang berlangsung dan menggunakan lembar observasi yang telah dibuat. Selama pelaksanaan kegiatan belajar mengajar dilakukan observasi oleh pengamat peneliti sendiri Pada akhir pelaksanaan siklus II diadakan tes selama I5 menit untuk mengukur hasil belajar siswa.

Refleksi

Pada tahap ini digunakan analisis terhadap seluruh penilaian, baik yang menyangkut penilaian proses (observasi guru dan siswa, afektif dan psikomotorik). Dengan demikian maka dapat diketahui hal-hal apa saja yang telah tercapai dan hal apa saja yang masih perlu diperbaiki pada siklus berikutnya.

\section{Analisis Data Hasil Belajar}

I. Data observasi

Data observasi yang diperoleh digunakan untuk merefleksi siklus yang telah dilakukan dan diolah secara deskriptif. Analisis data observasi menggunakan skala penilaian (Sudjana, 2006) pengukuran skala penilaian pada proses pembelajaran yaitu antara I dan 3. Makna dari nilai tersebut adalah semakin tinggi nilai yang 
dihasilkan semakin baik hasil pembelajaran, demikian juga sebaliknya semakin kecil nilai yang diperoleh maka semakin kurang baik pembelajaran. Nilai ditentukan pada kisaran nilai untuk tiap kriteria pengamatan. Penentuan nilai untuk tiap kriteria menggunakan persamaan sebagai berikut:

$$
\text { Rata-rata skor }=\frac{\text { Jumlah skor }}{\text { jumlah observasi }}
$$

Skor tertinggi $=$ jumlah butir skor $\mathrm{x}$ skor tertinggi tiap kriteria.

Skor terendah $=$ jumlah kriteria skor $\mathrm{x}$ skor terendah tiap criteria

Selisih skor $=$ skor tertinggi - skor terendah

Kisaran nilai tiap kriteria $=\frac{\text { selisih } \text { skor }}{\text { jumlah kriteria penilaian }}$

(Sudjana, 2006)

a. Lembar observasi aktivitas guru

Pada lembar observasi aktivitas sebagai guru terdapat II butir pertanyaan dengan kriteria penilaian I sampai 3.

Tabel I. Interval kategori penilaian aktivitas guru

\begin{tabular}{ccc}
\hline No & Kriteria & Skor \\
\hline I & Kurang & I-IO \\
2 & Cukup & II-20 \\
3 & baik & 2 I-30 \\
\hline
\end{tabular}

b. Lembar observasi untuk aktivitas siswa

Pada lembar observasi aktivitas guru terdapat II butir pertanyaan dengan kriteria penilaian I sampai 3.

Tabel. 2. Interval kategori penilaian aktivitas siswa

\begin{tabular}{ccc}
\hline No & Kriteria & Skor \\
\hline I & Kurang & I-I0 \\
2 & Cukup & I I-20 \\
3 & baik & I-30 \\
\hline
\end{tabular}

c. Observasi aktivitas afektif

Jumlah seluruh aspek observasi afektif ada 4 mecakup aspek kerjasama siswa, antusias siswa dalam mengajukan pertanyaan, presentasi, antusias siswa dalam menjawab pertanyaan, dengan jumlah kriteria penilaian I-4. penilaian ini dilakukan selama proses pembelajaran berlangsung yang disertai dengan descriptor setiap aspek.

Nilai afektif siswa $=\frac{\text { jumlah nilai afektif }}{\text { jumlah total }} \times 100$

Nilai rata - rata $=\frac{\text { jml nilai afektif semua siswa }}{\text { jumlah siswa }}$

d. Observasi aktivitas psikomotorik

Jumlah seluruh aspek psikomotorik ada empat yang mencakup aspek merangkai alat percobaan, menggunakan alat dan bahan, pengambilan data, pengembalian alat yang digunakan, dengan jumlah kriteria penilaian I- 4. penilaian ini dilakukan selama proses pembelajaran berlangsung yang disertai dengan descriptor setiap aspek.

nilai psikomotorik $=\frac{j m l \text { nilai } \text { sikomotorik }}{\text { jumlah total }} \times 100$

$$
\text { nilai rata }- \text { rata }=\frac{\text { jml nilai psikomotorik siswa }}{\text { jumlah siswa }}
$$

2. Data tes

Dalam penelitian ini, digunakan data secara deskriptif kualitatif dengan persentase (Arikunto, 1996). Hasil tes diolah dengan persen ketercapaian atau daya serap. Siswa dikatakan tuntas belajar secara individu bila mendapat nilai $\geq 7,0$, sedangkan secara klasikal proses belajar mengajar dikatakan tuntas bila siswa memperoleh nilai $\geq 7,0$ sebanyak 70\% (Depdikbud dalam Rahmi, 2010). Adapun rumus yang digunakan untuk perhitungan analisa data adalah:

Nilai Siswa $\quad X=\frac{B}{N} \times 100$

Keterangan: $\mathrm{X}=$ nilai siswa

$\mathrm{B}=$ jumlah jawaban benar

$\mathrm{N}=$ jumlah soal

Nilai Rata-Rata Hasil Belajar $X=\frac{\sum \mathrm{X}}{N}$

Keterangan: $\mathrm{X}=$ nilai rata-rata siswa

$\sum \mathrm{X}=$ jumlah nilai siswa

$\mathrm{N}=$ jumlah siswa (Sudjana, 2008)

Persentase Ketuntasan Belajar (KB) secara Klasikal

$$
D s=\frac{\text { jumlah skor yang nilainya } \geq 7,0}{\text { jumlah siswa }} \times 100 \%
$$

Kriteria keberhasilan tindakan diterapkan berdasarkan ketuntasan belajar yang diterapkan oleh sekolah dan berdasarkan pertimbangan peneliti. Indikator keberhasilan dalam penelitian ini, antara lain: a) Nilai siswa secara individu meningkat dari siklus I dan siklus 2, dan rata-rata nilai siswa secara klasikal mampu mencapai ketuntasan kriteria mengajar (KKM) yaitu $\geq$ 70 mencapai $70 \%$; b) Siswa dikatakan aktif dalam pembelajaran biologi dengan menggunakan pendekatan Sains Lingkungan Teknologi Masyrakat (saling temas) jika hasil observasi keaktifan siswa mengalami peningkatan dan mencapai nilai 70 .

\section{Hasil dan Pembahasan}

\section{Refleksi Awal}

Sebelum dilaksanakan siklus I, terlebih dahulu diadakan tes awal. Berdasarkan hasil belajar siswa pada tes awal masih cukup rendah yaitu dengan rata-rata 5,3. Tes ini dimaksud untuk mengukur tingkat pemahaman 
materi siwa sebelum dimulainya materi pada pokok bahasan arti, prinsip dasar dan jenis-jenis bioteknologi dan implikasinya.

Siklus I

Pada siklus I pembelajaran bioteknologi dengan pendekatan Sains Lingkungan Teknologi Masyarakat dalam pembelajaran Biologi di SMA N I Kotapadang, kelas XII KD: 5.I. Menjelaskan arti, prinsip dasar dan jenis-jenis bioteknologi dan implikasinya pada saling temas dilaksanakan dalam I kali pertemuan. Pelaksanaan pembelajaran dilakukan sesuai dengan rencana pembelajaran yang telah disusun oleh peneliti dan guru dalam rencana pelaksanaan pembelajaran. Selama pelaksanaan kegiatan pembelajaran berlangsung, proses pembelajaran diamati oleh dua orang observer. Yang bertindak observer I adalah peneliti dan observer 2 adalah guru biologi kelas X SMAN I Kotapadang kabupaten Rejang Lebong. Observasi ini dilakukan guna mengetahui sejauh mana aktivitas pembelajaran Bioteknologi, yaitu aktivitas guru dan keaktifan siswa.

Berdasarkan hasil observasi yang dilakukan oleh kedua observer, dapat dideskripsikan aktivitas guru, aktivitas siswa dan hasil belajar siswa sebagai berikut:

a. Deskripsi hasil observasi aktivitas guru dengan menggunakan pendekatan sains lingkungan teknologi masyarakat

I. Siklus I

Pada proses pembelajaran menggunakan pendekatan sains lingkungan teknologi masyarakat pada kompetensi dasar 5.I. Menjelaskan arti, prinsip dasar dan jenis-jenis bioteknologi dan implikasinya pada saling temas oleh dua orang pengamat pada aktivitas guru dalam katagori cukup. Dari hasil observasi data keseluruhan terlihat ada beberapa aspek yang diamati berada pada kategori kurang. Aspek-aspek yang termasuk dalam katagori kurang antara lain: I) guru membagi siswa membagi siswa menjadi beberapa kelompok yang heterogen, 2) membagi LKS kepada siswa, 3) membimbing siswa melakukan percobaan dan mengerjakan LKS, 4) membimbing siswa melakukan percobaan dan mengerjakan LKS dan 5) guru membimbing siswa untuk melakukan presentasi di depan kelas. Hasil analisis data observasi aktivitas guru pada siklus I dapat dilihat pada tebel dibawah ini :

Tabel 3. Hasil analisis data observasi aktivitas guru

\begin{tabular}{cc}
\hline Pengamat & Nilai \\
\hline $\mathrm{I}$ & 20 \\
2 & $2 \mathrm{I}$ \\
Jumlah & $4 \mathrm{I}$ \\
Rata-rata & 20,5 \\
Katagori penilaian & Cukup \\
\hline
\end{tabular}

Berdasarkan hasil analisis data aktivitas guru pada siklus I yang dilakukan oleh pengamat I dan pengamat 2 diperoleh nilai rata-rata sebesar 20,5 Yang termasuk dalam katagori cukup.

b. Deskripsi observasi terhadap aktivitas siswa

I. Siklus I

Pada proses pembelajaran menggunakan pendekatan sains lingkungan teknologi masyarakat pada kompetensi dasar 5.I. Menjelaskan arti, prinsip dasar dan jenis-jenis bioteknologi dan implikasinya pada saling temas oleh dua orang pengamat pada aktivitas siswa dalam katagori cukup. Dari hasil observasi data keseluruhan terlihat ada beberapa aspek yang diamati berada pada kategori kurang. Aspek-aspek yang termasuk dalam katagori kurang antara lain: I) siswa duduk berdasarkan kelompok yang telah ditentukan, 2) menerima LKS dari guru, 3) memperhatikan tugas belajar yang berhubungan dengan masalah yang akan dikerjakan, 4) siswa melakukan percobaan dan mengerjakan LKS dan 5) siswa melakukan presentasi di depan kelas.

Hasil analisis data observasi aktivitas siswa pada siklus I dapat dilihat pada tebel dibawah ini:

Tabel 4. Hasil analisis data observasi aktivitas siswa

\begin{tabular}{cc}
\hline Pengamat & Nilai \\
\hline I & I9 \\
2 & I7 \\
Jumlah & 36 \\
Rata-rata & I8 \\
Katagori penilaian & cukup \\
\hline
\end{tabular}

Berdasarkan hasil analisis data aktivitas siswa pada siklus I yang dilakukan oleh pengamat I dan pengamat 2 diperoleh nilai rata-rata sebesar I8 yang termasuk dalam katagori cukup. Menurut Slavin (2006) dalam dalam Asyari (20II:85) pembelajaran dengan pendekatan saling temas mengandung pengertian bahwa dalam belajar kooperatif siswa belajar bersama, saling menyumbang pikiran dan bertanggung jawab terhadap pencapaian hasil belajar secara individu maupun kelompok. Hal ini juga sejalan dengan pendapat Solihatin (2008) dalam Asyari (20II :86) pembelajaran dengan menggunakan pendekatan saling temas, pengembangan kualitas diri siswa terutama aspek afektif dapat dilakukan secara bersama-sama. Belajar dalam kelompok kecil dengan prinsip pendekatan saling temas dapat digunakan untuk mencapai tujuan belajar, baik yang fungsinya kognitif, afektif maupun psikomotorik. Suasa belajar yang berlangsung dalam interaksi saling percaya, terbuka dan rileks diantara anggota kelompok.

Hasil pengamatan yang dilakukan oleh observasi pada siklus I nilai aktivitas siswa yang belum tuntas, terlihat belum optimalnya 
pelaksanaan pada tahap: a) Tahap invitasi, siswa telah memahami isyu-isyu aktual tentang pandangan atau anggapan masyarakat terhadap tempe yang diberikan guru namun belum mampu menanggapi isyu-isyu yang diberikan guru; b) Tahap ekplorasi, siswa telah mengetahui bioteknologi modern dan bioteknologi tradisional namun belum dapat membedakan contoh dari produk bioteknologi modern dan contoh produk bioteknologi tradisional; c) Tahap action, siswa telah mencari informasi tentang bagaimana cara membuat tempe, namun belum tau langgaranlanggaran dalam proses pembuatan tempe.

c. Deskripsi nilai afektif.

\section{Siklus I}

Pada proses pembelajaran menggunakan pendekatan sains lingkungan teknologi masyarakat pada kompetensi dasar 5.I. Menjelaskan arti, prinsip dasar dan jenis-jenis bioteknologi dan implikasinya pada saling temas oleh peneliti pada aktivitas siswa dalam katagori belum tuntas (data lengkap lampiran 2I) dari hasil observasi data keseluruhan terlihat ada beberapa aspek yang diamati berada pada skor dua. Hasil analisis data observasi nilai afektif pada siklus I dapat dilihat pada tebel dibawah ini:

Tabel 5. Data nilai afektif siswa

\begin{tabular}{ll}
\hline \multicolumn{1}{c}{ Aspek penelitian } & \multicolumn{1}{c}{ Siklus I } \\
\hline Rata-rata & $69, \mathrm{I} 4$ \\
Ketuntasan & $43,75 \%$ \\
Kategori & Belum tuntas \\
\hline
\end{tabular}

Berdasarkan hasil analisis data nilai afektif siswa pada siklus I yang dilakukan oleh peneliti diperoleh nilai rata-rata sebesar 69,I4 dengan ketuntasan klasikal 43,75\% yang termasuk dalam katagori belum tuntas. Solihatin (2008) dalam Asyari (20II :86) pembelajaran dengan menggunakan pendekatan saling temas, pengembangan kualitas diri siswa terutama aspek afektif dapat dilakukan secara bersama-sama. Belajar dalam kelompok kecil dengan prinsip pendekatan saling temas dapat digunakan untuk mencapai tujuan belajar, baik yang fungsinya kognitif, afektif maupun psikomotorik. Suasa belajar yang berlangsung dalam interaksi saling percaya, terbuka dan rileks diantara anggota kelompok. Hasil pengamatan yang dilakukan oleh peneliti pada siklus I nilai aktivitas siswa yang belum tuntas, terlihat belum optimalnya pelaksanaan pada tahap: a) Kerjasama siswa, siswa dapat memberikan penjelasan kepada teman tapi tidak menyetujui pendapat temannya; b) Antusias siswa dalam mengajukan pertanyaan, siswa dapat menajukan pertanyaan dengan jelas namun belum lengkap; c) Presentasi, Siswa tidak dapat persentasi karena pada siklus I belum ada hasil diskusi kelompok; d) Antusias siwa dalam menjawab pertanyaan, siswa berusaha menjawab pertanyaan dengan benar, tapi masih bingung.

d. Deskriptif nilai psikomotorik

I. Siklus I

Pada proses pembelajaran menggunakan pendekatan sains lingkungan teknologi masyarakat pada kompetensi dasar 5.I. Menjelaskan arti, prinsip dasar dan jenis-jenis bioteknologi dan implikasinya pada saling temas oleh peneliti pada aktivitas siswa dalam katagori belum tuntas dari hasil observasi data keseluruhan terlihat ada beberapa aspek yang diamati berada pada skor 2 . Hasil analisis data observasi nilai psikomotorik pada siklus I dapat dilihat pada tebel dibawah ini

Tabel 6. Data nilai psikomotorik siswa

\begin{tabular}{|l|l|}
\hline \multicolumn{1}{|c|}{ Aspek penelitian } & \multicolumn{1}{c|}{ Siklus I } \\
\hline Rata-rata & $75,2 \mathrm{I}$ \\
\hline Ketuntasan & $68,75 \%$ \\
\hline Kategori & Belum tuntas \\
\hline
\end{tabular}

Berdasarkan hasil analisis data nilai psikomotorik siswa pada siklus I yang dilakukan oleh peneliti diperoleh nilai rata-rata sebesar 75,2I dengan ketuntasan klasikal 68,75\% yang termasuk dalam katagori belum tuntas. Hasil pengamatan yang dilakukan oleh peneliti pada siklus I nilai aktivitas afektif yang belum tuntas, terlihat belum optimalnya pelaksanaan pada tahap: a) Merangkai alat percobaan, siswa belum merangkai alat, karena pada siklus I belum ada percobaan; b) Menggunakan alat dan bahan, siswa belum menggunakan alat dan bahan percobaan, karena pada siklus I belum dilakukan percobaan; c) Pengambilan data, siswa belum dapat mengambil data, karena pada siklus I belum dilakukan percobaan; d) Mengembalikan alat yang digunakan, siswa belum mengembalikan alat percobaan yang digunakan pada tempatnya, karena pada siklus I belum dilakukan percobaan.

e. Deskripsi nilai akhir siswa

Tes siklus I dilaksanakan pada akhir pembelajaran. berdasarkan hasil tes, nilai tersebut dianalisis dengan mencari rata-rata kelas dan kriteria ketuntasan belajar secara klasikal. Hasil tes siswa kelas XII IPA I SMAN I Kotapadang kabupaten Rejang Lebong adalah sebagai berikut:

Tabel 7. Data nilai akhir siswa

\begin{tabular}{ll}
\hline \multicolumn{1}{c}{ Aspek penelitian } & \multicolumn{1}{c}{ Siklus I } \\
\hline Rata-rata & 6,2 \\
Ketuntasan & $43 \%$ \\
Kategori & Belum tuntas \\
\hline
\end{tabular}

Pada tabel di atas hasil belajar siswa pada siklus I memperoleh rata-rata 6,2 dengan ketuntasan 
klasikal $43 \%$ mendapat kategori belum tuntas. Karena kriteria ketuntasan mengajar menyebutkan bahwa persentase ketuntasan belajar siswa tuntas apabila tuntas $70 \%$ siswa mendapat nilai 7,0 untuk matapelajaran Biologi. Rendahnya nilai di atas dikarenakan beberapa faktor baik dari siswa maupun dari guru. Faktor penyebab rendahnya nilai pada siklus I antara lain adalah: a) guru tidak maksimal menggunakan pendekatan sains lingkungan teknologi masyarakat, b) guru kurang memahami karakteristik siswa, c) minat siswa dalam mengikuti pembelajaran masih rendah. Hal ini sejalan dengan pendapat Caroll dalam Yadi (20II:88) bahwa hasil belajar siswa dipengaruhi oleh lima faktor, yaitu (I) minat dan bakat belajar, (2) waktu yang tersedia untuk belajar, (3) kemampuan individu, (4) kualitas pengajaran, (5) lingkungan. Menurut Jones (2006) dalam Yadi (20II:88) akuntabilitas berkembang karena siswa harus saling melaporkan hasil pemikiran masingmasing dan berbagi (diskusi) dengan kelompokknya. Kemudian kelompok tersebut harus berbagi dengan seluruh kelas. Jumlah anggota kelompok yang kecil mendorong setiap anggota untuk terlibat aktif, sehingga siswa jarang atau bahkan tidak pernah berbicara di depan kelas. Sesuai dengan Etin (2008) dalam Asyari (2006 :89) pendekatan saling temas merupakan pendekatan yang dapat membantu siswa dalam mengembangkan pemahaman dan memecahkan masalah kehidupan nyata di masyarakat, sehingga dengan bekerja secara bersama-sama diantara sesame anggota kelompok akan meningkatkan motivasi, produktivitas, dan perolehan belajar.

Refleksi siklus I

Berdasarkan hasil pengamatan pembelajaran bioteknologi dengan menerapkan pendekatan sains lingkungan teknologi masyarakat diantara kedua pengamat ada yang memberikan kategori cukup bahkan kurang yaitu untuk deskripsi aktivitas guru adalah: I) guru membagi siswa membagi siswa menjadi beberapa kelompok yang heterogen, 2) membagi LKS kepada siswa, 3) membimbing siswa melakukan percobaan dan mengerjakan LKS, 4) membimbing siswa melakukan percobaan dan mengerjakan LKS dan 5) guru membimbing siswa untuk melakukan presentasi di depan kelas. Untuk aktivitas siswa adalah I) siswa duduk berdasarkan kelompok yang telah ditentukan, 2) menerima LKS dari guru, 3) memperhatikan tugas belajar yang berhubungan dengan masalah yang akan dikerjakan, 4) siswa melakukan percobaan dan mengerjakan LKS dan 5) siswa melakukan presentasi di depan kelas. untuk mengatasi aspek-aspek yang masih berada pada kategori kurang dan cukup pada siklus I seperti analisis data observasi guru dan siswa yang diberikan oleh dua orang pengamat, hal-hal yang perlu diperbaiki pada kegiatan pembelajaran siklus selanjutnya adalah:

a. Deskripsi aktivitas guru

Sebelum kegiatan pembelajaran bioteknologi dengan menerapkan pendekatan saling temas pada kompetensi dasar 5.2 Menjelaskan dan menganalisis peran bioteknologi serta implikasi hasil- hasil bioteknologi pada Saling temas pada siklus II, adapun tahap-tahap perbaikkan oleh guru yang harus lebih ditekankan adalah sebagai berikut I) guru membagi siswa membagi siswa menjadi beberapa kelompok yang heterogen, 2) membagi LKS kepada siswa, 3) membimbing siswa melakukan percobaan dan mengerjakan LKS, 4) membimbing siswa melakukan percobaan dan mengerjakan LKS dan 5) guru membimbing siswa untuk melakukan presentasi di depan kelas.

b. Deskripsi aktivitas siswa

Sebelum kegiatan pembelajaran bioteknologi dengan menerapkan pendekatan saling temas pada kompetensi dasar 5.2 Menjelaskan dan menganalisis peran bioteknologi serta implikasi hasil- hasil bioteknologi pada Saling temas pada siklus II, adapun tahap-tahap perbaikkan oleh siswa dan yang lebih ditekankan adalah sebagai berikut I) siswa duduk berdasarkan kelompok yang telah ditentukan, 2) menerima LKS dari guru, 3) memperhatikan tugas belajar yang berhubungan dengan masalah yang akan dikerjakan, 4) siswa melakukan percobaan dan mengerjakan LKS dan 5) siswa melakukan presentasi di depan kelas.

Berdasarkana hasil tes siklus I diperoleh nilai hasil belajar rata-rata siswa dengan aspek afektif 69,I4 dengan ketuntasan sebesar 43,75\% psikomotorik 75,2I dengan ketuntasan sebesar $68,75 \%$, dan aspek kognitif dengan rata-rata siswa 6,2 dan ketuntasan belajar 43\%. Sehingga dapat disimpulkan bahwa ketuntasan klasikal belajar pada siklus I secara umum belum tercapai berdasarkan acuan yang diberlakukan di SMAN I Kotapadang, kabupaten Rejang Lebong, ketuntasan klasikalnya adalah 70\% dengan nilai hasil belajar $\geq 7,0$. Oleh karena itu, diperlukan perbaikkan dengan melaksanakan pembelajaran siklus II.

Siklus II

Pada siklus II pembelajaran bioteknologi dengan menerapkan pendekatan sains lingkungan teknologi masyarakat pada kompetensi dasar 5.2 Menjelaskan dan menganalisis peran bioteknologi serta implikasi hasilhasil bioteknologi pada Saling temas dilaksanakan dalam 2 kali pertemuan. Pelaksanaan pembelajaran dilakukan sesuai dengan rencana pembelajaran yang telah disusun oleh guru dalam rencana pelaksanaan pembelajaran. Selama pelaksanaan kegiatan pembelajaran berlangsung, proses pembelajaran diamati oleh dua orang observer. Yang bertindak observer I adalah peneliti dan observer 
2 adalah guru biologi kelas X SMAN I Kotapadang kabupaten Rejang Lebong.

Berdasarkan hasil observasi yang dilakukan oleh kedua observer, dapat dideskripsikan aktivitas guru, aktivitas siswa dan hasil belajar siswa sebagai berikut:

a. Deskripsi hasil observasi aktivitas guru dengan menggunakan pendekatan sains lingkungan teknologi masyarakat

I. Siklus II

Pada proses pembelajaran menggunakan pendekatan sains lingkungan teknologi masyarakat pada kompetensi dasar 5.2 Menjelaskan dan menganalisis peran bioteknologi serta implikasi hasil- hasil bioteknologi pada Saling temas oleh dua orang pengamat pada aktivitas guru dalam katagori baik. Dari hasil observasi data keseluruhan ada beberapa aspek yang diamati berada pada kategori cukup. Aspek-aspek yang termasuk dalam katagori cukup antara lain adalah I) mengkomunikasikan tujuan pembelajaran dan motivasi siswa, dan 2) mendefinisikan tugas belajar yang berhubungan dengan masalah yang akan dikerjakan. Hasil analisis data observasi aktivitas guru pada siklus II dapat dilihat pada tebel dibawah ini:

Tabel 8. Hasil analisis data observasi aktivitas guru

\begin{tabular}{cc}
\hline Pengamat & Nilai \\
\hline $\mathrm{I}$ & 28 \\
\hline 2 & 30 \\
\hline Jumlah & 58 \\
\hline Rata-rata & 29 \\
\hline
\end{tabular}

Katagori penilaian Baik

Berdasarkan hasil analisis data aktivitas guru pada siklus II yang dilakukan oleh pengamat I dan pengamat 2 diperoleh nilai rata-rata sebesar 29 yang termasuk dalam katagori baik.

b. Deskripsi observasi terhadap aktivitas siswa

I. Siklus II

Pada proses pembelajaran menggunakan pendekatan sains lingkungan teknologi masyarakat pada kompetensi dasar 5.2 Menjelaskan dan menganalisis peran bioteknologi serta implikasi hasil- hasil bioteknologi pada Saling temas oleh dua orang pengamat pada aktivitas siswa dalam katagori baik. Dari hasil observasi data keseluruhan ada beberapa aspek yang diamati berada pada kategori cukup. Aspek-aspek yang termasuk dalam katagori cukup antara lain adalah I) siswa mencatat judul/topik pembelajaran, dan 2) memperhatikan tugas belajar yang berhubungan dengan masalah yang akan dikerjakan. Hasil analisis data observasi aktivitas siswa pada siklus II dapat dilihat pada tebel dibawah ini:

Tabel 9. Hasil analisis data observasi aktivitas siswa

\begin{tabular}{cc}
\hline Pengamat & Nilai \\
\hline I & 29 \\
\hline 2 & 28 \\
\hline
\end{tabular}

\begin{tabular}{cc}
\hline Jumlah & 57 \\
\hline Rata-rata & 28,5 \\
\hline Katagori penilaian & Baik \\
\hline
\end{tabular}

Berdasarkan hasil analisis data aktivitas siswa pada siklus II yang dilakukan oleh pengamat I dan pengamat 2 diperoleh nilai rata-rata sebesar 29 yang termasuk dalam katagori baik.

c. Deskripsi nilai afektif.

I. Siklus II

Pada proses pembelajaran menggunakan pendekatan sains lingkungan teknologi masyarakat pada kompetensi dasar 5.2 Menjelaskan dan menganalisis peran bioteknologi serta implikasi hasil- hasil bioteknologi pada Saling temas oleh peneliti dalam katagori tuntas.

Hasil analisis data observasi nilai afektif pada siklus II dapat dilihat pada tebel dibawah ini:

Tabel I0. Data nilai afektif siswa

\begin{tabular}{ll}
\hline \multicolumn{1}{c}{ Aspek penelitian } & \multicolumn{1}{c}{ Siklus II } \\
\hline Rata-rata & 76,36 \\
\hline Ketuntasan & $90,62 \%$ \\
\hline Kategori & Tuntas \\
\hline
\end{tabular}

Berdasarkan hasil analisis data nilai afektif siswa pada siklus II yang dilakukan oleh peneliti diperoleh nilai rata-rata sebesar 76,36 dengan ketuntasan klasikal 90,62\% yang termasuk dalam katagori tuntas. Hasil pengamatan yang dilakukan oleh peneliti pada siklus II nilai aktivitas afektif siswa tuntas, terlihat sudah optimalnya pelaksanaan pada tiap tahap: a) Kerjasama siswa, siswa dapat memberikan penjelasan kepada teman dan menerima pendapat temannya; b) Antusias siswa dalam mengajukan pertanyaan, siswa dapat menajukan pertanyaan dengan jelas, lengkap tapi tidak ilmiah; c) Presentasi, siswa tidak dapat menyajikan hasil diskusi dengan terstruktur; d) Antusias siwa dalam menjawab pertanyaan, Siswa berusaha menjawab pertanyaan dengan benar.

\section{d. Deskriptif nilai psikomotorik}

I. Siklus II

Pada proses pembelajaran menggunakan pendekatan saling temas pada kompetensi dasar 5.2 Menjelaskan dan menganalisis peran bioteknologi serta implikasi hasil- hasil bioteknologi pada Saling temas peneliti dalam katagori belum tuntas (data lengkap lampiran 34). Hasil analisis data observasi nilai psikomotorik pada siklus I dapat dilihat pada tebel dibawah ini:

Tabel II. Data nilai psikomotorik siswa

\begin{tabular}{ll}
\hline \multicolumn{1}{c}{ Aspek penelitian } & \multicolumn{1}{c}{ Siklus II } \\
\hline Rata-rata & 83,78 \\
\hline Ketuntasan & I00\% \\
\hline Kategori & Tuntas \\
\hline
\end{tabular}

Berdasarkan hasil analisis data nilai psikomotorik siswa pada siklus II yang dilakukan oleh peneliti 
diperoleh nilai rata-rata sebesar 83,78 dengan ketuntasan klasikal $100 \%$ yang termasuk dalam katagori tuntas. Hasil pengamatan yang dilakukan oleh peneliti pada siklus II nilai aktivitas psikomotorik sudah tuntas, terlihat optimalnya pelaksanaan pada tiap tahap: a) Merangkai alat percobaan, siswa merangkai rangkaian alat sesuai dengan petunjuk dalam LKS dan dapat merangkai tanpa bantuan guru; b) Menggunakan alat dan bahan, siswa menggunakan alat dan bahan percobaan dengan tepat dan benar; c) Pengambilan data, siswa mencatat data dengan benar dan jelas namun kurang lengkap; d) Mengembalikan alat yang digunakan, siswa memasukkan alat ketempanya dan memasukkan alat keposisis semula.

e. Deskripsi nilai akhir siswa

Tes siklus II dilaksanakan pada akhir pembelajaran. berdasarkan hasil tes, nilai tersebut dianalisis dengan mencari rata-rata kelas dan kriteria ketuntasan belajar secara klasikal. Hasil tes siswa kelas XII IPA I SMAN I Kotapadang kabupaten Rejang Lebong adalah sebagai berikut:

Tabel I2. Data nilai akhir siswa

\begin{tabular}{ll}
\hline \multicolumn{1}{c}{ Aspek penelitian } & Siklus II \\
\hline Rata-rata & 7,3 \\
\hline Ketuntasan & $74 \%$ \\
\hline Kategori & Tuntas \\
\hline
\end{tabular}

Pada tabel di atas, dapat dilihat proses pembelajaran biologi dengan pendekatan saling te sains lingkungan teknologi masyarakat pada siklus II sudah tuntas, karena berdasarkan yang diberlakukan di SMAN I Kotapadang, kabupaten Rejang Lebong, ketuntasan klasikalnya adalah $70 \%$ dengan nilai hasil belajar $\geq$ 7,0 .

\section{Refleksi siklus II}

Berdasarkan pemaparan di atas, bahwa pada siklus II mengalami peningkatan proses pembelajaran yang dilakukan oleh guru maupun siswa sudah dikatakan baik, Karena dari 10 aspek yang dinilai 8 aspek sudah dikatakan kategori baik. Proses pembelajaran yang dilihat dari aktivitas guru dan siswa yang sudah mencapai katagori baik pada siklus II berdampak pula pada hasil belajar siswa yang memperoleh nilai rata-rata 7,3 dengan ketuntasan klasikal yaitu 74\%. Hasil belajar yang diperoleh sudah dikatakan tuntas dengan kuntasan ktriteria mengajar yang diberlakukan di SMAN I Kotapadang, kabupaten Rejang Lebong, ketuntasan klasikalnya adalah 70\% dengan nilai hasil belajar $\geq 7,0$ untuk mata pelajaran Biologi.

\section{Simpulan}

Penerapan pendekatan Sains Teknologi Lingkungan Masyarakat pada pokok bahasan Bioteknologi di kelas XII IPA ${ }^{I}$ SMAN I kotapadang Kabupaten Rejang Lebong dapat meningkatkan aktivitas dan hasil belajar siswa yaitu pada siklus I 6,2 dengan ketuntasan 43\% dan pada siklus ke II menjadi 7,3 dengan ketuntasan $74 \%$

\section{Daftar Pustaka}

Arikunto. Suharsimi. 2006. Prosedur Penelitian. Jakarta: Rineka Cipta

Asyari, 2006. Penerapan Pendekatan STM Dalam Pembelajaran Sains di SD. Depdiknas. Direktorat Dikti.

Galib, La Maronta. (200I). Penerapan Model Konstruktif Pembelajaran Sains dan Teknologi dengan Pendekatan Sains Teknologi Masyarakat dan Strategi Pembelajaran Modul di Sekolah Dasar Kecil Negeri Bungin. Disertasi Doktoral Program Studi Pendidikan IPA PPS. UPI.

Hamalik, oemar. 200I. Perencanaan Pengajaran Berdasarkan Pendekatan Sistem. Jakarta: Bumi Aksara

Hasan. Iqbal. 2006. Pokok-pokok materi statistic I (statistic deskriptiff). Jakarta: Bumi aksara.

Sudjana. Nana. 2006. Penilaian Hasil Proses Belajar Mengajar. Bandung: Transitu.

Winarni, Endang W. 2009. Mengajar IPA Secara Bermakna. Bengkulu: Unib press.

Yadi. hendri. 20I I. Upaya Meningkatkan Kualitas Proses Dan Hasil Belajar Ipa Pada Siswa Kelas 4a Sdm 07 Kota Bengkulu Melalui Model Kooperatif Tipe Think-Paire-Share. Skripsi UNIB : bengkku 